\title{
EFFECTIVENESS OF BREAST CARE ON THE SMOOTH DELIVERY OF BREAST MILK
}

\author{
Agus Sulistyowati ${ }^{1 *}$ \\ ${ }^{1}$ Kerta Cendekia Nursing Academy, Sidoarjo \\ *Correspondence: \\ Agus Sulistyowati \\ Email: agussulistyowati78@gmail.com
}

\begin{abstract}
The breastfeeding program for babies is very encouraged by the government on the grounds that there are many benefits of breastfeeding that can be given to babies. One of the supporting factors for the success of the program is to prepare the breast so that it can produce abundant milk and contains lots of nutrients. Preparation of pregnant women to provide quality breastfeeding is by treating the breast during pregnancy in the final trimester of pregnancy. Warm massage and compresses on the breast have several effects, including improving blood flow and making the nipple more elastic and not easily scratched when breastfeeding later.
\end{abstract}

Key words: Pregnant women, breast care, breastfeeding.

\section{INTRODUCTION}

The government is currently promoting an exclusive breastfeeding program for newborn babies up to 6 months of age. To succeed the program, it must be prepared as well as possible what things can make the mother ready to breastfeed the baby as early as possible and prepare so that breast milk can come out smoothly so that the exclusive breastfeeding program can be carried out properly. One of them is by preparing the breast so that it can provide quality breast milk. Breast preparation can be done in several ways, including the breast care during the final trimester of pregnancy. Breast care is one of the actions that can be done during childbirth (breastfeeding) so that it can facilitate the production of breast milk (Saleha, 2009).

Based on the results of research by Astari and Djuminah in the Journal of Nursing Studies at Dr. Saiful Anwar Malang reported that $80 \%$ of primiparous postpartum mothers who had breast care during the antenatal period had been able to produce breast milk after childbirth, while only $26.7 \%$ of the primiparous postpartum mothers who did not breast care after giving birth (Asti \& Djuminah, 2008). According to The Indonesian Ministry of Health (2010), the percentage of coverage of infants who received exclusive breastfeeding up to 6 months was only $15.3 \%$ in North Sulawesi, the coverage of babies who received exclusive breastfeeding was only $2.6 \%$. The Indonesian Ministry of Health revealed the causes of infant mortality in Indonesia, including low birth weight babies (29\%), asphyxia (27\%), tetanus and infections (15\%), drinking problems (10\%), hematological problems $(6 \%)$, diarrhea and pneumonia (13\%) (The Indonesian Ministry of Health, 2008).

There are 2 factors in the mother's ability to breastfeed her baby, namely internal factors and external factors. Internal factors include lack of maternal knowledge about lactation management. External factors such as breast milk have not been released on the first day, so the mother thinks there is an need for additional formula milk. Mother's ignorance about 
colostrum and many mothers who think that mothers who are malnourished will produce breast milk that is of poor quality (Baskoro, 2008).

Breast care during pregnancy is intended to prepare the breast to be ready to be filled with breast milk. Breast care steps, including massage and compressing which aims to make blood flow through the breast more smoothly and make the production of breast milk more smoothly and ready to be given immediately when the baby is born.

\section{THEORY REVIEW}

\section{Pregnant Mother}

At the time of human development, one of the tasks of development in adulthood is pregnancy and childbirth. Pregnancy in adulthood can occur not only in one phase, but continues to repeat according to the number of children desired in a family. Pregnancy is a period that starts from conception to the birth of the fetus (Wiknjosastro, 2005). During pregnancy, there are various changes experienced by the mother's body, so the mother must be ready to adapt. Adaptation is both physiological and psychological. One of these physiological changes occurs in the breast of a pregnant woman.

Breasts as target organs for breastfeeding experience many changes as preparation after the fetus is born. These changes are as follows:

1. During pregnancy, the breasts will get bigger, tense, and heavy;

2. Palpable nodules caused by alveoli gland hypertrophy;

3. Shadow veins will be clearly visible and more bluish;

4. Hyperpigmentation of the areola and nipple;

5. If squeezed, yellow milk (colostrum) will come out (Mochtar, 1998).

\section{Breast Care During Pregnancy}

Some of the goals of breast care are to maintain breast hygiene, flex and strengthen the nipples, the treated breasts will produce enough milk for the baby's needs. Good breast care will make a mother do not need to worry about the shape of her breasts will change quickly, so it is less attractive anymore. In addition, good breast care will cause the nipples to not blister when sucked by the baby, expedite the flow of breast milk, overcome a flat or immersed nipple so that it can stand out more so that it can be sucked by the baby (The Indonesian Ministry of Health, 2006).

Time for breast care can be done during pregnancy and after childbirth. The implementation is usually done twice a day. According to Saleha (2009), breast care can be carried out with the following steps:

1. Apply cotton that has been given coconut oil or baby oil for \pm 5 minutes, then the nipples are cleaned;

2. Stick both palms between the two breasts;

3. Massage starts upwards, sideways, then downwards. In the massage process, position the left palm towards the left side, right palm towards the right side;

4. The massage continues downward, sideways and then transversely, then the palms massage forwards then the hands are released from the breast, repeat the movement 20-30 times;

5. The left hand supports the left breast, then the three fingers of the right hand make a circular motion while pressing which starts from the base of the breast to the nipple. Perform the same stage in the right breast. Perform this movement as much as twice the movement in each breast;

6. One hand supports the breast, while the other hand massages the breast with the little side from the edge toward the nipple. Perform the same stage in both breasts. Do this movement about 30 times;

7. After massage, the breast is watered by using warm and cold water alternately for \pm 5 minutes, dry the breast with a clean towel and then use a clean and supportive bra.

With regular breast care in the last trimester of pregnancy it is hoped that the problems that exist in the breast during pregnancy can be resolved properly. Common problems that occur in the breast during pregnancy, among others chafed nipples, nipples do not protrude and dams on the breast (Saryono dan Pramitasari on Sulistyowati, Putra, \& Umami, 2017). 


\section{Benefits of Breastfeeding}

Mother's milk is a type of food that is sufficient for all physical, psychological, social, and spiritual elements. Mother's milk contains nutrients, hormones, immune elements, antiallergic, and anti-inflammatory. Nutrition in Mother's Milk includes nearly 200 elements of the baby's food ingredients (Hubertin, 2003). Mother's Milk contains high-quality nutrients that are useful for the growth and development of baby's intelligence. Factors that form brain cells, especially high levels of DHA, are found in breast milk. Mother's milk also contains Whey (the main protein of milk in the form of liquid) more than casein (the main milk-shaped protein). So that breast milk can be easily absorbed by the baby (Rulina, 2007).

Newborns already have immunity called immunoglobulin obtained from the mother through the placenta, but soon after the birth process this substance will drop dramatically, even though the baby's body has not been able to produce immunoglobulin itself well. In this situation, the immunoglobulin gap occurs in the baby's body, so the role of breast milk can erase or at least reduce the gap. Because breast milk contains immune substances that can protect babies from various infectious diseases, bacteria, viruses and fungi. Colostrum contains immunoglobulin substances 10-17 times more than soybean milk (Cahyadi, 2007).

\section{REFERENCES}

Astari, A. M. \& Djuminah. (2008). Hubungan Perawatan Payudara Masa Antenatal dengan Kecepatan Sekresi ASI PostPartum Primipara. Journal of Nursing Studies, 1.

Baskoro, A. (2008). ASI Panduan Praktis Ibu Menyusui. Yogyakarta: Banyu Media.

Cahyadi, W. (2007). Kedelai, Kasiat, dan Teknologi. Jakarta: Bumi Aksara.

Department of Health of East Java Province. (2007). Standar Pelayanan Minimal. Accessed on February, 2017 from http://www.dinkes-jatim.com.

Hubertin Sri, P. (2003). Konsep Penerapan ASI Ekslusif. Jakarta: EGC.

Mochtar, R. (1998). Sinopsis Obstetri: Obstetri Fisiologi, Obstetri Patologi. Jakarta: EGC.

Saleha, S. (2009). Asuhan Kebidanan pada masa nifas. Jakarta: Salemba Medika.
Suharyono, S Rulina, A Firmansyah. (2007), Air Susu Ibu Tinjauan dari Berbagai Aspek, Faculty of Medicine, University of Indonesia, Jakarta, pp. 51-64.

Sulistyowati, A., Putra, K. W. R., \& Umami, R. (2017). Hubungan antara Usia dan Tingkat Pendidikan dengan Tingkat Pengetahuan Ibu Hamil tentang Perawatan Payudara selama Hamil di Poli Kandungan RSU Jasem, Sidoarjo. Nurse and Health, 6(2), 40-43.

Suririnah, D. (2007). ASI Menyelamatkan Jiwa Bayi. Accessed on February, 2018 from http//www.kompas.com.

Suririnah, D. (2008). Beberapa perubahan pada ibu hamil. Accessed on April 12, 2016 from http://Infobunda.com.

Suririnah, D. (2009). Buku pintar merawat bayi 0-12 bulan. Jakarta: PT Gramedia Pustaka.

The Indonesian Ministry of Health. (2006). Perawatan Payudara. Accessed on February, $\quad 2017$ from http://www.depkesri.co.id.

The Indonesian Ministry of Health. (2008). Program Perencanaan Persalinan Dan Pencegahan Komplikasi.

The Indonesian Ministry of Health. (2010). Laporan Riset Kesehatan Dasar (Riskesdas) 2010. Jakarta: Badan Litbangkes, Depkes RI.

Wiknjosastro, H. (2005). Ilmu Kebidanan. Jakarta: Yayasan Bina Pustaka Sarwono Prawirohardjo.

Cite This Article As: Sulistyowati, A. Effectiveness of Breast Care on the Smooth Delivery of Breast Milk. Nurse and Health: Jurnal Keperawatan 2018; 7(2): 121-123. 